Attachment Theory, Child Maltreatment and Family Support 


\section{Also by David Howe:}

Social Workers and their Practice in Welfare Bureaucracies An Introduction to Social Work Theory

The Consumers' View of Family Therapy

with Sawbridge, P. and Hinings, D. Half a Million Women: Mothers

Who Lose Their Children by Adoption

On Being a Client: Understanding the Process of Counselling and

Psychotherapy

Attachment Theory for Social Work Practice

Attachment and Loss in Child and Family Social Work

Adopters on Adoption: Reflections on Parenthood and Children

Patterns of Adoption: Nature, Nurture and Psychosocial

Development

\section{Also by Gillian Schofield:}

The Youngest Mothers

\section{Also by Marian Brandon and Gillian Schofield:}

Social Work with Children 


\title{
Attachment Theory, Child Maltreatment and Family Support
}

A Practice and Assessment Model

\author{
David Howe \\ Marian Brandon \\ Diana Hinings \\ Gillian Schofield
}

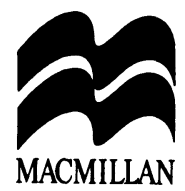




\section{$2 \pi$}

(C) David Howe, Marian Brandon, Diana Hinings and Gillian Schofield 1999

All rights reserved. No reproduction, copy or transmission of this publication may be made without written permission.

No paragraph of this publication may be reproduced, copied or transmitted save with written permission or in accordance with the provisions of the Copyright, Designs and Patents Act 1988, or under the terms of any licence permitting limited copying issued by the Copyright Licensing Agency, 90 Tottenham Court Road, London W1P 0LP.

Any person who does any unauthorised act in relation to this publication may be liable to criminal prosecution and civil claims for damages.

The authors have asserted their right to be identified as the authors of this work in accordance with the Copyright, Designs and Patents Act 1988.

Published 1999 by MACMILLAN PRESS LTD

Houndmills, Basingstoke, Hampshire RG21 6XS and London

Companies and representatives throughout the world

ISBN 978-0-333-74978-4 ISBN 978-1-349-14975-9 (eBook)

DOI 10.1007/978-1-349-14975-9

A catalogue record for this book is available from the British Library.

This book is printed on paper suitable for recycling and made from fully managed and sustained forest sources.

$\begin{array}{cccccccccc}10 & 9 & 8 & 7 & 6 & 5 & 4 & 3 & 2 & 1 \\ 08 & 07 & 06 & 05 & 04 & 03 & 02 & 01 & 00 & 99\end{array}$

Editing and origination by Aardvark Editorial, Mendham, Suffolk 


\section{Contents}

List of Figures and Tables vi

Acknowledgements vii

1 Introduction: working with families and children 1

Part I: The Theory Behind the Practice 7

Introduction 9

2 Understanding attachment theory 12

3 Measuring attachment across the lifespan 31

4 Secure and autonomous patterns 46

5 Avoidant, defended and dismissing patterns 61

6 Ambivalent, dependent and preoccupied patterns $\quad 87$

7 Disorganised, controlling and unresolved patterns 122

Part II: Applying the Theory to Practice 167

Introduction 169

8 Gathering information for assessment 174

9 Analysing, assessing and classifying the information 196

10 Formulating the aims of intervention 230

11 Introducing protective mechanisms and processes 246

12 The sites and focus of intervention 266

13 Conclusion 292

Bibliography 296

Author index 308

$\begin{array}{ll}\text { Subject index } & 310\end{array}$ 


\section{List of Figures and Tables}

Figures

A Developmental attachment theory: practice and assessment model

9.1 Internal working model: representations of self 207

9.2 Internal working model: representations of others 211

10.1 Hierarchy of aims 240

12.1 Focus of interventions 266

12.2 Attachment patterns and behaviours 277

\section{Tables}

3.1 Attachment behaviours and patterns across the lifespan 45

9.1 Assessment and attachment classification 198 


\section{Acknowledgements}

In 1996, we approached Norfolk Social Services Department to ask whether we could work with a small group of child and family social workers and their team managers. The aim was to see whether we could translate and adapt the exciting ideas that were being generated in developmental attachment theory to the world of child and family social work. Norfolk responded generously. Five social workers and four team managers volunteered to take part, curious but uncertain about what they might be letting themselves in for. We worked together for almost 2 years, meeting regularly, discussing case material, thinking through assessment implications, rehearsing possible interventions, drinking much tea and coffee, eating a fair tonnage of chocolate biscuits. We also met, interviewed and talked with many children and parents who were being seen by the social, health and psychological services. The families' help and cooperation was invaluable, and we would like to record our considerable appreciation for their time and interest. However, our greatest thanks must go to the team of social workers and team managers:

Sheila Burgoyne
Mike Chilton
Suzy Gardner
Owen Garrod
Chris Downes
Susan Lee
Jim McLauchlan
Hugh Morgan
Marilyn Smith

Throughout the 2 years, their commitment to the project did not waver and their enthusiasm was a source of great encouragement. The relevance of an attachment perspective in day-to-day work, although always apparent in theory, gradually became clear in practice. Over 
the 2 years, the shape of an assessment and practice model based on developmental attachment theory began to take form. The end product is the present book. Case material was also discussed individually with Dawn Gregory and Sheila Fearnley in a series of extremely stimulating sessions. Their time and expertise provided further opportunities to think through and refine our ideas. We would also like to thank Anne Borrett, Heather Cutting and Leslie Barrett who typed many of our audiotaped interviews. Our final thanks go to Julia Warner, a wizard at creating diagrams and complicated box tables, all of which helped to give graphic expression to our evolving thoughts and ideas.

DAVID Howe, MaRIAN BRANDON, DiANa Hinings, GILLIAN SCHOFIELD University of East Anglia, Norwich 